\title{
Establishment of a Rat Strain with Testicular Hypoplasia and its Morphological Observations
}

\author{
Hirofumi FUJITA**, Hiroshi IKADAI, Yoshio AGEMATSU, \\ Katsushi SUZUKI* and Tomonori IMAMICHI* \\ The Imamichi Institute for Animal Reproduction, 3-100 Nissin-cho, \\ Omiya-shi, 330 *Department of Physiology, Nippon \\ Veterinary and Zootechnical College, 1-7-1 Kyonan-cho, \\ Musashino-shi, Tokyo, 180 Japan
}

(Received for publication: September 14, 1982)

A testicular hypoplastic $(\mathrm{T}-\mathrm{H})$ rat strain, originating from the WistarImamichi rat colony at the Institute for Animal Reproduction, has been maintained by full-sib matings since 1974 for eight filial generations. There were no abnormal signs in external features and growth patterns of the T-H strain. Testicular hypoplasia was detectable at about 8 weeks of age by palpation around the scrotum. Unilateral or bilateral testicular abnormalities were detected in 80 out of 391 males of this strain. The incidences were $32.5 \%$ for right side, $48.8 \%$ for left and $18.8 \%$ for both respectively. Reproductive performance of unilateral $\mathrm{T}-\mathrm{H}$ males were not different from that of normal. While bilateral ones showed normal sexual behavior, they failed to produce their progenies. In adult $\mathrm{T}-\mathrm{H}$ rats testicular weight was approximately two-fifth of the normal, and the accessory organs such as the seminal vesicules, epididymis and etc., especially located in the same side of the testicular hypoplasia, reduced their size and weight. Occasionally was seen lack or denaturation of the deferent duct or epididymis. At adult age, no spermatogenesis was observed in all hypoplastic testes with a few exception, and normal spermatogenesis in the testis of the normal side of unilateral $\mathrm{T}-\mathrm{H}$ male.

\section{異常小精巣ラットの育成と形態学的観察}

\author{
藤田博文**.筏井 洋・上松嘉男・鈴木勝士*・今道友則* \\ 動物繁殖研究所 \\ *日本獣医畜産大学
}

ラットにおける遺伝的精巣発育不全としては LongEvans 系 [5], King-Holtzman 交雑系 [2], Wistar 系と Long-Evans 系との交雑系 [4]での報告がみられ る。後二者に扰いては体毛着色制限遗伝子（常染色体性
優性遗伝子; $\mathrm{H}^{\mathrm{re}}$ ) 又は指欠損遺伝子(常染色体性劣性 遺伝子；hd）の多面作用として精巣発育不全が生じると されている。

著者らは Wistar-Imamichi ラットコロニーにおい

**Present Adress: Teikyo University School of Medicine, 2-11-1 Kaga, Itabashi-ku, Tokyo, 173 Japan（帝京大医学部） 
てたまたま発見された 1 例の精巣発育不全雄ラットを起 源とし，異常小精巣ラットを分離育成しつつある。本系 統の精巣異常は片側性又は両側性に発現し，片側精巣発 育不全の場合には妊性を有するが，両側精巣発育不全の 場合には不妊となる。

本報では 8 世代までの観祭に基づき，異常小精巣ラッ 卜の繁殖, 発育および形態学的特徵について述べる。

\section{材料および方法}

由来扣よび家系調查: 1974 年, 動物繁殖研究所 Wistar-Imamichi ラット維持集団 [1] 内で触診により 1 例の雄ラットに片側精巣の発育不全が観察された。こ の雄ラットと生存姉妹とを親世代とし，兄妹交配により 継代を続けた（Fig. 1)。また本系統の親世代となった 雄ラットの近縁個体 252 例について精巣異常および類似 の症例に関する家系調査を行なった。

継代方法, 精巣異常個体の発現率および繁殖成績: 両 側性異常小精巣ラットは後述の如く妊娠を成立させるこ

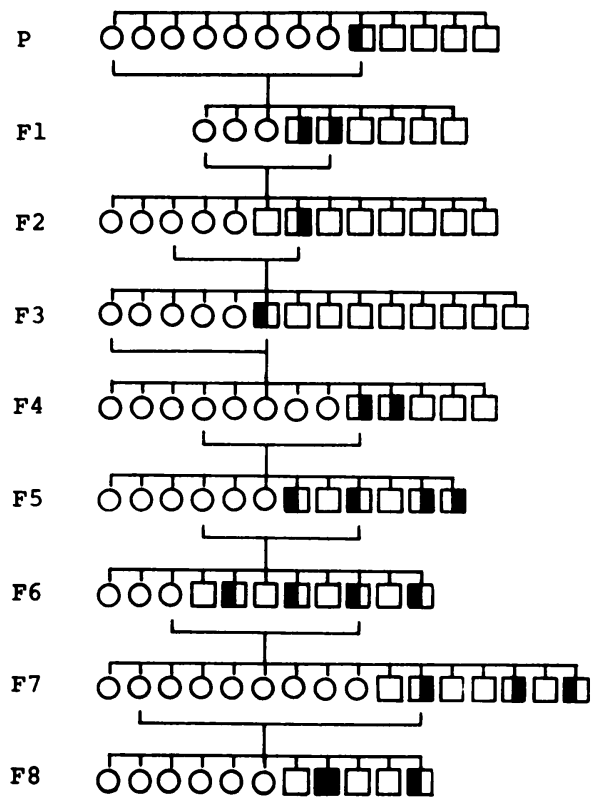

\footnotetext{
: Bilateral testicular hypoplastic male D. Unilateral testicular hypoplastic male : Normal male

: Female
}

Fig. 1 A part of the pedigree chart of the testicular hypoplastic rat originating from the Wistar-Imamichi rat
とができないので，継代にあたり片側性異常小精巣ラッ トを種雄として使用した。雌ラットでは繁殖性に影響を およぼす異常をほとんど認めなかったので，種親におけ る選抜基準はとくに設けなかった。片側性異常精巣雄に より継代された各世代について精巣異常個体の発現率を 集計した。また雨側性精巣異常個体の 6 例, 片側精巣異 常個体42例および同腹の表現型上正常な個体 2 例を本系 統の雌52例と交配した成績（受胎率，分婏率および産仔 数）を集計し,ささらに交配時の性行動についても観察し た。

成長： $5 \sim 17$ 週齢まで毎週，異常小精巣ラット10例お よびその同腹正常仔11例の体重を測定した。また同時に 精巣を陰襄外部より触診し, 精巣異常の触知が可能な週 齢を検索した。

形態学的観察：6〜8 ケ月齢の両側性異常小精巣ラッ ト 6 匹，片側性異常小精巣ラット10匹および対照群とし て同腹の正常精巣ラット11匹を用い生殖器および主要内 分泌臟器の重量を検索した。体重, 体長, 尾長の測定後 エーテル深麻酔にて動物を屠殺解剖し，内部諸葴器にお ける異常の有無を観察した。ついで精巣, 精巣上体, 精 管, 精䧶, 凝固腺, 包皮腺, 精管腺, 前立腺, 陰茎, 副 腎および下垂体を摘出し秤量した。各臟器を10\%ホルマ リン液にて固定した後, 常法によりパラフィン包埋し薄 切，へマトキシリン・エオジン染色を施して鏡検した。 また剖検された動物のうち 3 匹の両側性異常小精巣ラッ トと 8 匹の片側性異常小精巣ラットについて, 精巣, 精 巣上体の頭部および尾部をそれぞれの中央部で切断し， 今道らの方法 [3]に準拠して生理食塩液を約 $0.1 \mathrm{ml}$ 滴下 したスライドグラス上に塗抹し，值ちに 150 倍で精子の 存否を検索した。

\section{成}

家系調查：基礎動物（親世代）となった異常小精巣ラ ットの両親又はその兄妹を片親として繁殖された 1,029 匹の仔（雌526匹，雄503匹）の5ち調査が可能であった 118 匹の雄ラット拈よび，基礎動物の祖父母文はその兄 妹を片親として繁殖された 777匹の仔（雌 378匹，雄399 匹）のうち134匹の雄ラットの合計252匹を調査した。そ の結果異常小精巣あるいは類似の疾患を持つ雄ラットは 発見されなかった。

継代成績，精巣異常個体発現率および繁殖成積：8世 代まで兄妹交配された異常小精巣ラットの一家系の家系 図を Fig. 1 に示した。精巣異常は片側性又は両側性に 
Table 1. Incidence and affected side of the testicular hypoplasia

\begin{tabular}{|c|c|c|c|c|c|}
\hline \multirow{2}{*}{ Generation } & \multicolumn{2}{|c|}{ No. of Animals } & \multicolumn{3}{|c|}{ affected side } \\
\hline & Tested & Affected & Right & Left & Bilateral \\
\hline $\mathrm{P}$ & 3 & $1(33.3)$ & $1(100)$ & $0(0)$ & $0(0)$ \\
\hline $\mathrm{F} 1$ & 8 & $2(25 \cdot 0)$ & $0(0)$ & $2(100)$ & $0(0)$ \\
\hline $\mathrm{F} 2$ & 22 & $1(4.5)$ & $0(0)$ & $1(100)$ & $0(0)$ \\
\hline F 3 & 15 & $3(20.0)$ & $1(33.3)$ & $1(33.3)$ & $1(33.3)$ \\
\hline $\mathrm{F} 4$ & 48 & $9(18.8)$ & $2(22 \cdot 2)$ & $4(44.4)$ & $3(33.3)$ \\
\hline F 5 & 127 & $15(11.8)$ & $5(33.3)$ & $8(53.3)$ & $2(13.3)$ \\
\hline $\mathrm{F} 6$ & 87 & $24(27.6)$ & $7(29.2)$ & $13(54.2)$ & $4(16.7)$ \\
\hline F 7 & 59 & $15(25.4)$ & $4(26.7)$ & $7(46.7)$ & $4(26.7)$ \\
\hline F 8 & 22 & $10(45.5)$ & $6(60.0)$ & $3(30.0)$ & $1(10.0)$ \\
\hline Total & 391 & $80(20.5)$ & $26(32.5)$ & $39(48.8)$ & $15(18.8)$ \\
\hline
\end{tabular}

Numbers in parenthesis show $\%$

Table 2. Reproductive performance in the testicular hypoplastic rat

\begin{tabular}{lccc}
\hline & Bilateral & Unilateral & Normal $^{1)}$ \\
\hline No. of males & 6 & 42 & 2 \\
No. of females mated & 20 & 124 & 8 \\
No. of conception & 0 & 109 & 7 \\
No. of delivery & 0 & 107 & 7 \\
litter size & 0 & $10.1 \pm 3.4$ & $10.9 \pm 1.9$ \\
\hline
\end{tabular}

1) Normal siblings in the testicular hypoplastic rat strain.

2) Values represent Mean \pm S. D.

No significant differences were seen in all the parameters between normal and unilateral testicular hypoplastic rat groups.

発現し, 片側性の場合には左右いずれにも発現した。

Table 1 に片側精巣異常個体を 親とした各世代での 精巣異常個体発現率を示した。8世代までの391例中 80 例 (20.5\%) に精巣異常が認められた。精巣異常は, 片 側性のものが65例, 両側性のものが15例認められ, 片側 性の異常発現例が多かった。片側性異常では左側買常が 39例, 右側異常が26例であり, 左側異常個体が多く発現 した。

8 世代までに繁殖に供された片側性および両側性異常 小精巣雄ラットの繁殖成績と, 対照として同腹兄弟中に みられた表現型上正常な雄ラットの繁殖成績を Table 2 に示した。片側性異常小精巣およびこれらの正常雄ラ ット群ではいずれも交尾行動が垫められ，交配に供した 全ての雄に打いて妊性をもつことが確認された。また耐
群における雌ラットの受胎率, 分婏率および産仔数の間 に有意な差は認められなかった。一方両側性異常小精巣 雄ラット6匹と雌20匹との交配においては, 交尾行動と 臸栓の形成は認められたが，全ての交配組合せにおいて 同居期間（26～93日間）中に妊娠の成立は認められなか った。

成長：異常小精巣雄ラットならびに同腹の正常雄ラッ トの成長曲線および異常小精巣の検出週齢を Fig. 2 に 示した。成長期を通じ異常小精巣ラットと正常雄ラット の体重に有意な差は恋められなかった。また精巣は陰襄 内に下降しており, 外見上正常雄ラットと区別し難かっ た。しかし，陰萝部の触診では， 8 週齢頃より精巣の大 きさの違いが認められた。

形態学的特徵 : 片側性異常小精巣ラット 1 例の生殖器 


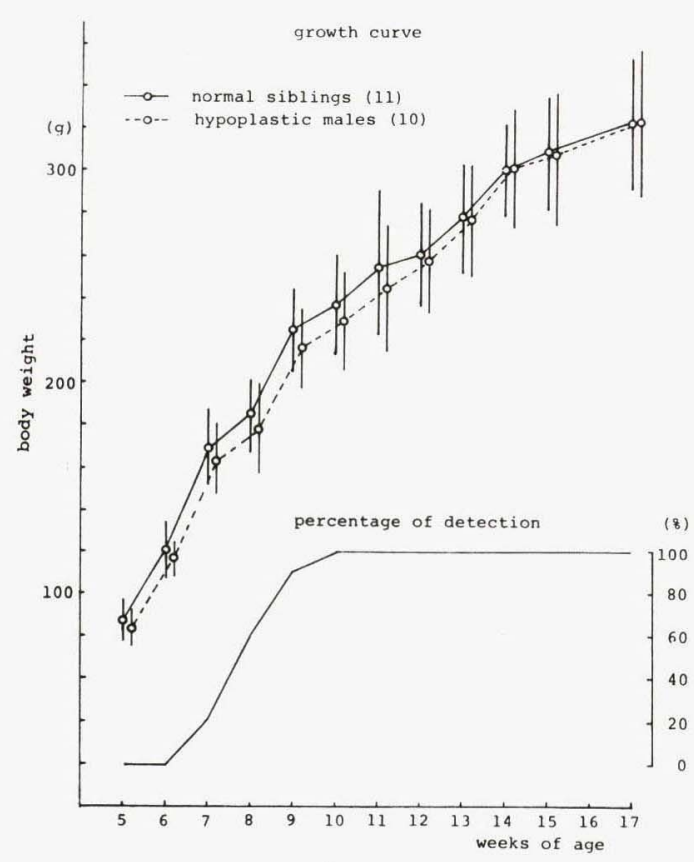

Fig. 2 Growth curve of male testicular hypoplastic rats and percent incidences for the testicular hypoplasia

Normal male siblings descended from unilateral testicular hypoplastic males.

Percentage of detection: (No. testicular hypoplastic rats detected in each week/Total No. testicular hypoplastic rats) $\times 100$

( ) : No. of rats observed.

系諸臟器の形状を Fig. 3 に示した。写真に示した個体 では左側精栄の発育不全と同側の精巣上体の萎縮が観察 されるが，その他の臟器に異常は認められなかった。解 剖された16匹の異常小精巣ラット（両側性 6 匹，片側性 10匹）において精巣の欠損例は認められなかったが，精 巣上体の欠損 ( 2 匹, 臟器数にして 2 例), 精巣上体の 萎縮 (10匹, 同14例) および精管と精管腺の欠損ないし 痕跡 ( 9 匹, 同11例) が認められた。

Table 3 に異常小精巣ラット拉よび同腹正常精巣ラ ットの解剖成績を示した。両側性異常小精巣ラットで は, 精巣, 精巣上体, 精管, 精囊, 凝固腺, 包皮腺, 精 管腺, 前立腺背葉および副腎の重量が対照群に比較して 有意に軽かった。一方片側性異常小精巣ラットでは, 対 照群と比較して精囊, 凝固腺, 精管腺, 前立腺背葉およ

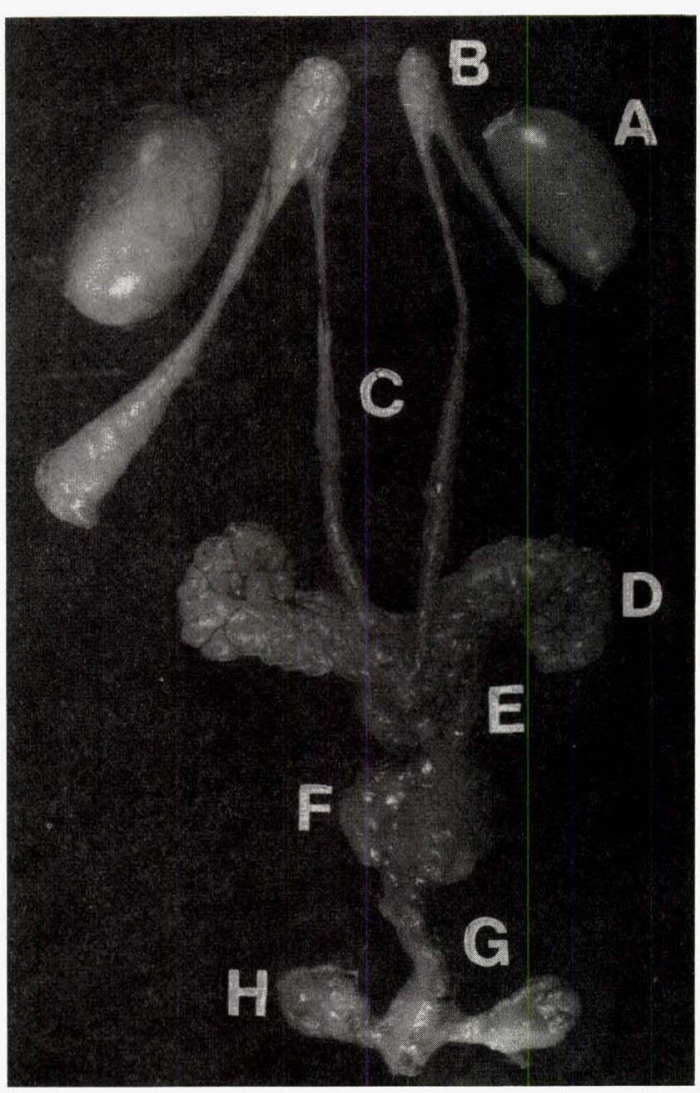

Fig. 3 Genital organs of an unilateral testicular hypoplastic rat. testis(A), epididymis(B), ductus deference(C), seminal vesicle and coagulating gland(D), dorsal prostate(E), ventral prostate and bladder $(F)$, penis $(G)$ and preputial gland(H).

び副腎の重量は有意に軽く,さらに異常側の精巣, 精巣 上体および精管の重量も軽かった。なお臟器重量の検索 に供されなかった個体についても, 肉眼的病理解剖を行 ったが，雄では異常小精巣と副生殖器の発育不全のほか には，特記すべき異常は認められなかった。また雌では 第 5 世代の 1 例に左卵宩の近位での子宮盲端例を確認し たにとどまった。

塗抹標本による精子の検査成積を Table 4 に示し た。片側性異常小精巣ラットでは正常側の精巣, 精巣上 体の標本で全ての検査例において精子像が確認された。 異常側の精巣上体の塗抹標本では精子像は確認されなか った。異常側精巣の塗抹標本 8 例のうち 4 例では精子は 認められず残り 4 例では精子は存在したが極めて少なか った。両側珄の異常小精巣ラットでは全ての検査例にお 


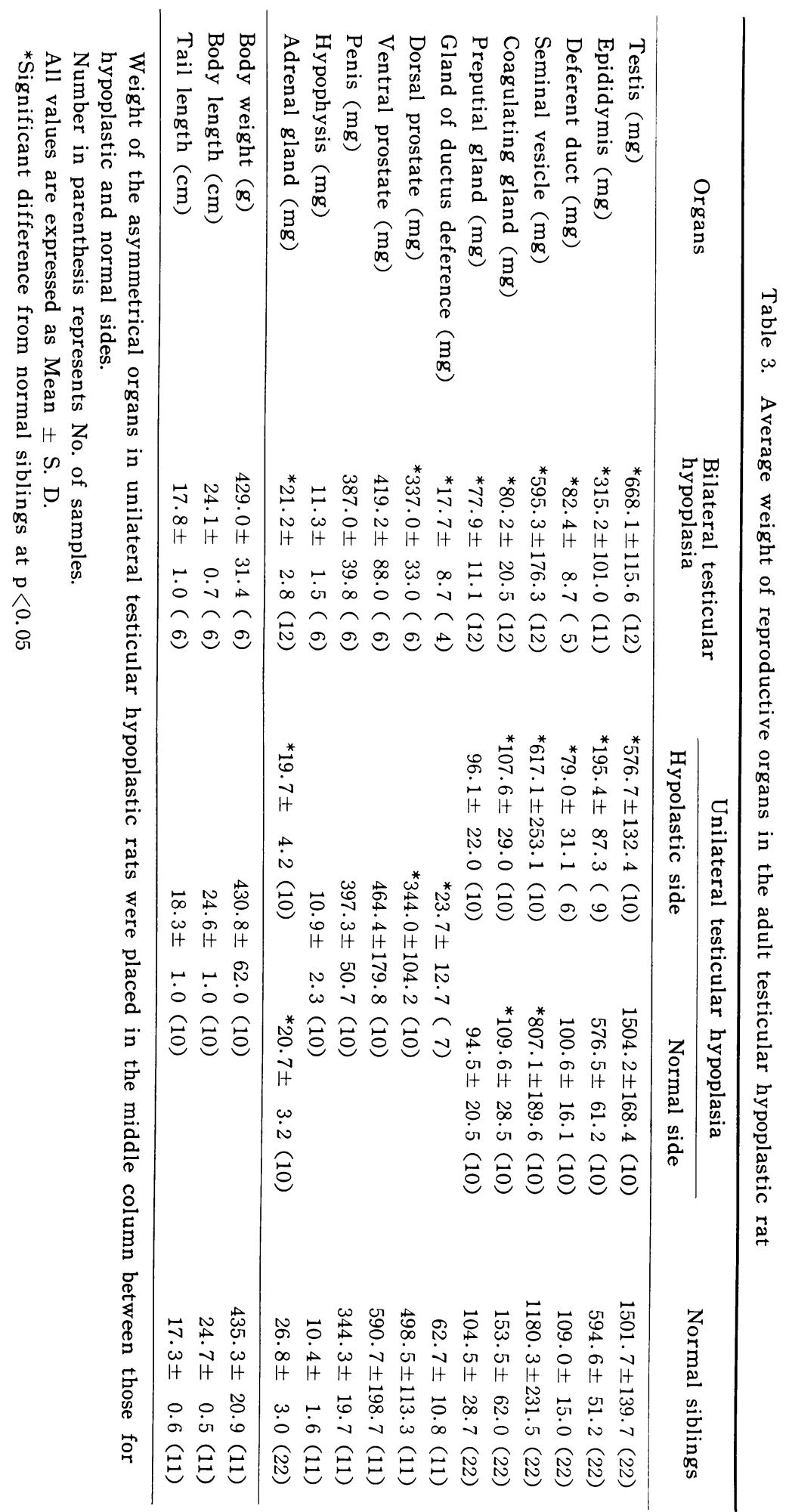


Table 4. Observation on the spermatozoa in testicular and epididymal smears of adult testicular hypoplastic rats

\begin{tabular}{|c|c|c|c|c|c|c|c|c|c|c|c|c|c|c|c|}
\hline & \multicolumn{5}{|c|}{ Testis } & \multicolumn{5}{|c|}{ Caput Epididymis } & \multicolumn{5}{|c|}{ Cauda Epididymis } \\
\hline & - & \pm & + & H & $H^{*}$ & - & \pm & + & H & H & - & \pm & + & H & HI \\
\hline \multicolumn{16}{|c|}{ Unilateral Testicular Hypoplastic (8) } \\
\hline Hypoplastic side & 4 & 2 & 2 & 0 & 0 & 8 & 0 & 0 & 0 & 0 & 8 & 0 & 0 & 0 & 0 \\
\hline Normal side & 0 & 0 & 1 & 5 & 2 & 0 & 0 & 1 & 2 & 5 & 0 & 0 & 0 & 0 & 8 \\
\hline \multicolumn{16}{|c|}{ Bilateral Testicular Hypoplastic (3) } \\
\hline Hypoplastic sides & 6 & 0 & 0 & 0 & 0 & 6 & 0 & 0 & 0 & 0 & 6 & 0 & 0 & 0 & 0 \\
\hline
\end{tabular}

* : Judged according to the description by Imamichi and Agematsu [3]

- : No spermatozoa are found in the entire field of the smear

\pm : A questionable fragment of spermatozoa is detected in the entire field of the smear.

+ : A few spermatozoa are observed in every microscopic field.

H : Crowded spots of spermatozoa are observed in several microscopic fields.

II : Compactly crowded spermatozoa are observed.

Number in parenthesis represents No. of animals tested.

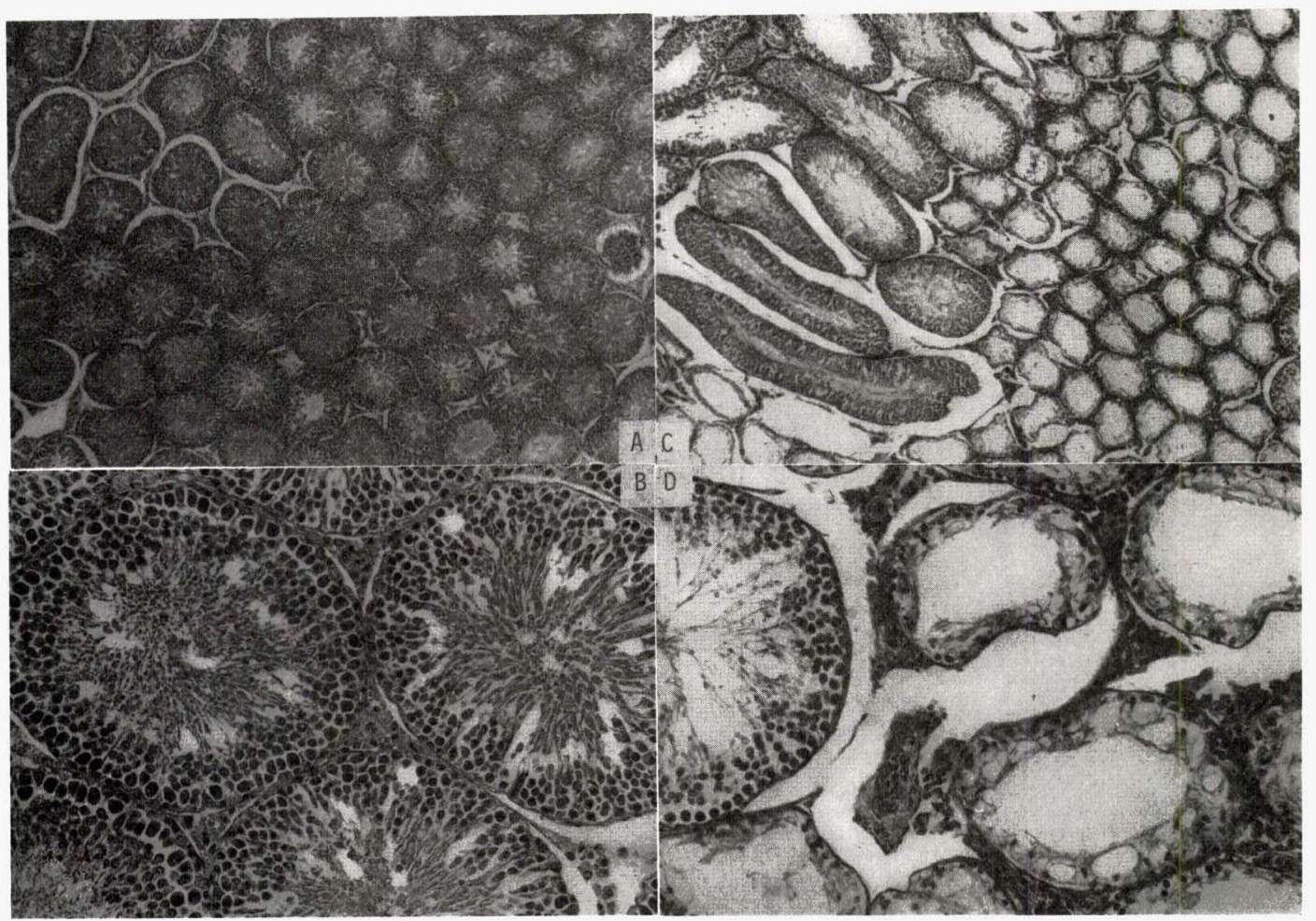

Fig. 4 Histological observations on the testis of the testicular hypoplastic rat

A : Testis, normal side of T-H rat, stained with hematoxyline eosin $(\times 68)$

B : High magnification of $\mathrm{A}(\times 680)$

C : Hypoplastic testis Most of the seminiferous tubules degenerated severely, but some of them still remained normal $(\times 68)$

D : High magnification of $\mathrm{B}(\times 680)$ No spermatogenesis was seen in the degenerated tubules. 
いて, 左右精巣, 精巣上体の頭部扣よび尾部の塗抹標本 中に精子像は確漶されなかった。

Fig. 4 に片側性異常小精单ラットの正常側と買常側の 精巢の組織写真を示した。異常側精巣の精細管では, 一 部に正常な精細管上皮細胞と精子形成が認められたがほ とんどの精細管はその径を減じ, 固有膜の肥厚, 大部分 の精細管上支細胞の変性, 久損および精子形成不全が観 察された。また精細管の間隙を占める Leydig 細胞は萎 縮・変性し，一見結合織様の細胞が増生しているかのよ らな感を呈した。

\section{考 察}

著者らの継代した買常小精巣ラットに打いて精巣異常 は片側もしくは両側性に認められ，異常精巣は大きさお よび重量が著しく小さい。Gumbreck ら[2] は精巣発

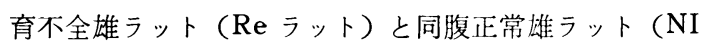
ラット）の精巣重量を比較し，NI ラットでは約90日齢 で最大重量に達するのに対し， Re ラットでは乳仔期よ り精巣の発達が荤延し, 約60日秢で最大重量（正常精栄 の約 $1 / 4 ）$ に達し, 以後增加することなく成体になると 報告している。Moutier ら[4]も Hypodactyly 雄亏 ットの精巣で $\operatorname{Re}$ ラットと同様な傾向（最大重量期 10 週龄，精巣重量は12週龄で正常精巣の約 1/3）を観察し ている。著者らの異常小精巣ラットでは外部触診による 精巣異常の早期検出は 7 〜 䓢柃で可能であるが, 成体 の精巢の大きさは正常精策の約 $2 / 5$ であった。この值は 正常に発育している Wistar-Imamichi ラットの 6 〜 7 週齢の精巣の大きさ [3]に相当する。従って, 著者ら の異常小精巣ラットでは 8 週㱓前後より精巣の発達が停 滞するものと推測される。

両側性異常小精巣ラットの場合, 正常な交尾行動を示 し, 腔栓の形成もみられたが, 雌ラットを娃娠させるこ とはできなかった。これに対し片側性異常小精巣ラット では，正常雄ラットに相当する繁殖成績が認められた。 片側性異常小精巣ラットでは, 正常側の精巣が機能をも つため繁殖能力を保持しているものと考えられる。精巣 発育不全ラットの妊性については Gumbreck ら [2], Moutier 5 [4], 武田 [7], 臬山ら [9]の㪕告がみられ る。片側性買常小精巣ラットは，妊性といら点では片側 性陰金雄ラットに類似しているが，その精栄は陰慗内の 所定の位置まで下降している。

塗抹標本による精子検査と組織学的観察によれば，異 常精巣ではほとんどの場合に精子形成不全ごあったが，
少量の精子が認められる例もあった（片側性異常小精巣 8 例中 4 例)。Smelser [5]は精巣発育不全雄ラットに 拈いて 5 ないし 6 個の精原細胞が見られた例外的な 1 例 があったが，その他の例では精子形成は全く認められな かったと報告している。Moutier ら[4]は，発育不全精 巣に敃いて微量の精子の存在を恋め, かつ 9 11週柃の 数例において連動性をもつ精子を垫めたが，それらの精 子はしばしば形態的に異常な精子であったと報告してい る。著者らのラットにおいては異常精子は確認されなか った。

異常小精巣ラットの異常精巣の組織学的な検索におい て, 精細管径の狭小, 精子形成の低下, 変性した Leydig 細胞などの所見が特徵的であった。Gumbreck ら [2] は出生時から成体に至るまでの精巣発育不全ラット $(R e$ 系) の精巣を組織学的に検討し, 発育不全精巣の精子形 成は正常雄ラットに比べて発達が遅れ，数例においては 一時的に受精可能な精子形成期像がみられたが，大多数 の成体では著者らと同様の組織像であると報告してい る。

翼常小精巣雄ラットの副生殖器は一般に正常雄ラット の副生殖器より小さい傾向があり, 特に片側性異常小精 紧ラットでは精栄発育不全側の精巣上体や精襄などの副 生殖器が正常精巣側の副生殖器より有意に小さかった。 精栄上体あるいは精管においては時に久損が㤎められた が, 精襄や凝固腺, 前立腺等の副生殖器については欠損 例はなかった。生殖器系およびそれと発生学的に近縁な 泌尿器系の耐者の久損例としては $\mathrm{ACI} / \mathrm{NS}$ 系統が知ら れている。鈴木 [6]は $\mathrm{ACI} / \mathrm{NS}$ 系統の腎臓欠損例の雄 ラットに拈いて低頻度ではあるが，精囊の欠損および同 側の精巣の萎縮を報告している。著者らの異常小精巣ラ ットにおいては, 腎葴もしくは精襄の欠損を併なう例は 観察されなかった。一方, 田内ら［8]は高頻度に先天性 水腎症を発現する系統を Wistar-Imamichi ラットよ り継代分離したが，その系統においては逆に精巣異常の 合併例は認められていない。

精巣発育不全を伴ならラットの体成長について Smelser[5], Moutier ら [4] は正常であることを観察 した。Re 系では Gumbreck ら［2]は同腹の正常雄ラ ットと詳細に比較した結果, 生後 5 日目から 100 日目に かけてわずかながら成長速度が遅いが，110日目では正 常ラットの体重に追いつくことを観察した。異常小精巣 雄ラットに拈いては観察期間を通じ同腹の正常雄ラット の体重との間に有意差は認められなかった。本系統の精 巣発育不全を誘発する因子は, 体成長には影響を及ぼさ 
ないと言えよう。

精巣発育不全を誘発する遺伝要因について, Smelser [5]はメンデル比に従う単純劣性遺伝子を，Moutier[4] らは劣性遺伝様式をとる指久損遗伝子（遺伝子記号 hd） の精巣に対する多面作用を，また Gumbreck ら[2]は 優性遺伝様式をとる体毛着色制限遺伝子（遺伝子記号 $\left.\mathrm{H}^{\mathrm{re}}\right)$ の多面作用によることを報告しているが，これら の遺伝子はいずれもが常染色体性の単一遺伝子である。 本系統の精巣異常発現の遗伝様式を確めるためには今後 さらに検啥が必要である。

我々は現在本系統の継代，繁殖および特性の調査を継 続中である。

\section{要 約}

Wistar-Imamichi ラットにおいて偶然発見された 1 匹の異常小精巣ラットを兄妹交配により8 代継代し, 次 の成積を得た。1. 異常小精巣雄ラットは正常牡相を呈 し, 発育, 精巣の陰鐜内への下降とも正常で, 外観から は異常の有無を判別し難いが，院惑部の触診によれば 8 週路前後より精巣異常の検出が可能であった。2. 本系 統での精巣異常は 391例中 80例 $(20.5 \%)$ に発現し, 片 側性又は両側性である。異常個体80例中右側精巣異常は 26 例 $(32.5 \%$ ), 左側異常 39 例 $(48.8 \%$ ), 両側異常 15 例 (18.8\%) であった。3. 片側性異常雄ラットでは正常 雄ラットに相当する繁殖成績が得られた。両側性異常雄 ラットでは，交尾行動は正常であったにもかかわらず交 配結果は不妊であった。4. 異常小精巣雄ラットは正常 雄ラットに比べて精巣が小さい（正常精巣の約 2/5）ば かりでなく，異常精巣に付随する精巣上体や精囊などの 副生殖器が小さい傾向がみられ，しばしば精巣上体ある
いは精管の欠損が琹められた。 5 . 成熟時における異常 小精巣の塗抹標本もしくは組織学的検索によれば，一部 の例外を除きほとんどの場合に精子形成不全が喼められ た。しかし, 片側性異常小精巣ラットに护ける外観上正 常な精巣では，精子形成過程像が観察された。

本研究の組織所見について御助言を頂いた東北大学農学部莱 池建機博士に深く感謝します。

\section{文献}

［1］藤田博文・若藤靖压・上松嘉男 - 今道友則 (1980). Wistar-Imamichi ラットの乳頭数の変異について, 実験 動物, 29, 61-66

[2] Gumbreck, L., Stanley, A. J., Allison, J. E., and Easley, R. B. (1972). Restriction of color in the rat with associated sterility in the male and heterochromia in both sexes. J. Exp. Zool., 180, 333-350

［3］今道友則・上松嘉男 (1962). HCG の造精機能促進作用 に関する研究ならびに精子形成作用の検定法についての 基礎的検剖, 日獸大紀要, 11, 31-46.

[4] Moutier, R., Toyama, K., and Charrier, M. F. (1973). Hypodactyly a new ressesive mutation in the Norway rat. J. Hered., 64, 99-100

[5] Smelser, G. K. (1936). Spontaneous sterility in the male rat. Anat. Rec. 64 (Suppl.), 53.

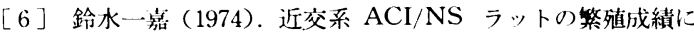
ついて. 尖験動物, 23, 129-136.

[7] 武田 満 (1959). Rat に掞ける遺伝的 cryptorchidism の偶発例。実験動物，8,184

［8］田内清害・鈴木勝士・今道友則（1980）。高頻度に先天性 水腎症を発生するラットの育成とその形態学的特徴. 先天 異常, 20, 1-6

［9］遠山紀代子・今道友則（1971）.ラットにおける hydrotestis (水腫样精巣) に関寸る基䂣的研究 I ，交配実験に よる hydro-testis ラットの不妊性の確認. 日獣大紀要, 19, $17-20$ 